\title{
Simulasi Otomatisasi Pengoperasian pompa Air Untuk Mengatur Ketinggian Air Danau di Bandar Udara Internasional Juanda Surabaya Berbasis Arduino Uno
}

\author{
Fiqqih Faizah ${ }^{1}$ \\ Wempy Brilliansya ${ }^{2}$ \\ Program Studi D3 Teknik Listrik Bandar Udara \\ Akademi Teknik dan Keselamatan Penerbangan Surabaya \\ Jl. Jemur Andayani I No. 73 Surabaya \\ Email : \\ ${ }^{1}$ fiqqihfaizah@gmail.com \\ ${ }^{2}$ wempy.brilliansya@yahoo.co.id
}

\begin{abstract}
ABSTRAK
Melubernyaair danau dapat terjadi di Bandar Udara Internasional Juanda Surabaya karena banyaknya air yang ditampung dan terlambatnya kerja pompa air untuk mengalirkan air dari danau ke sungai. Sistem pengoperasian pompa dipandang belum efektif dan efisien karena masih dilakukan secara manual dengan cara teknisi harus datang ke lokasi untuk memeriksa tingkat ketinggian air dan mengoperasikan pompa. Selain itu, jarak dari ruang teknisi dan rumah pompa cukup jauh sehingga memerlukan waktu untuk mencapainya.Oleh karena itu, penelitian ini dirancang untuk membantu memudahkan kerja para teknisi dengan memodelkan sistem otomatisasi penyalaan pompa berdasarkan kondisi ketinggian air di danau dan sungai. Prototip alatmemanfaatkan sensor ultrasonik HC-SR04 untuk mendeteksi ketinggian air dan sensor arus ACS-712 untuk mendeteksi arus dari pompa. Optimasi sistem penyalaan pompa menggunakan metode daftar prioritas (priority list) dari beberapa pompa air yang tersedia.
\end{abstract}

Kata Kunci: danau, sungai, pompa submersible, sensor ultrasonik HC-SR04, sensor arus ACS-712, Arduino Uno

\section{Pendahuluan}

Bandar Udara Internasional Juanda Surabaya adalah salah satu bandar udara yang dikelola oleh PT. Angkasa Pura I (Persero), yaitu merupakan Badan Usaha Milik Negara(BUMN) yang bergerak dalam bidang pengusahaan jasa kebandar-udaraan.Seperti halnya bandar-bandar udara komersil lainnya, Bandar Udara Internasional Juanda Surabaya juga mempunyai tugas pokok untuk melaksanakan pemberian jasa pelayanan operasi keselamatan lalu lintas udara.Dalam pencapaian tugas pokoknya, pelayanan yang diberikan juga harus didukung dengan rasa nyaman bagi para penumpang baik yang akan berangkat maupun yang baru datang. Salah satu fasilitas untuk keselamatan penerbangan diantaranya adalah keberadan danau di wilayah Bandar Udara Internasional Juanda Surabaya.

Danau, acapkali disebut juga sebagai waduk, menurut pengertian umum adalahcekungan di permukaan bumi yang cukup luas dandigenangi oleh air, kemudian air yang melimpah tersebut dimanfaatkan untuk berbagai keperluan lainnya pada saat musim kemarau. Air yang ditampung di danau tidak hanya berasal dari hujan, melainkan berasal dari air limbah kotoran dari terminal yang sudah diolah untuk menghilangkan bakteri dan bau. Fungsi utama dibangunnya danau ini adalah untuk mengatasi agar runway tidak pecah-pecah pada saat musim kemarau. Kondisi runway yang pecahpecah dapat berakibat fatal bagi penyelenggaraan penerbangan. 
Untuk mengantisipasi gangguan pada danau, pihak bandar udara menyediakan pompa yang digunakan untuk membuang air danau ke sungai maupun laut pada saat ketinggian air danau melebihi batas akibat hujan ataupun banyaknya air pembuangan kotoran yang telah diolah.Pengoperasian pompa masih dilakukan secara manual, yaitu teknisi harus menuju ke lokasi untuk melihat level danau dan mengoperasikan pompa. Hal ini dipandang kurang efektif dan efisien mengingat jarak ruang teknisi ke rumah pompa (pump house) yang terletak di dekat danau cukup jauh.Oleh karena itu, keberadaan sebuah sistem pengoperasian pompa secara otomatis diharapkan dapat meningkatkan efektivitas dan efisiensi kinerja teknisi sertakeselamatan dan kenyamanan di lingkungan bandar udara.

\section{Danau di Bandar Udara Internasional Juanda Surabaya}

Bandar Udara Internasional Juanda Surabaya memiliki 2(dua) buah danau. Danau yang pertama berada di ujung runway 28 dan danau kedua berada di ujung runway 10 dengan ukuran $\pm 1690 \mathrm{~m}^{3}$. Setiap danau memiliki 6 (enam) buah pompa dengan kapasitas masing-masing 10 PK yang digunakan untuk memompa air ke sungai. Pompa yang digunakan merupakan jenis pompa submersible atau disebut juga pompa benam.

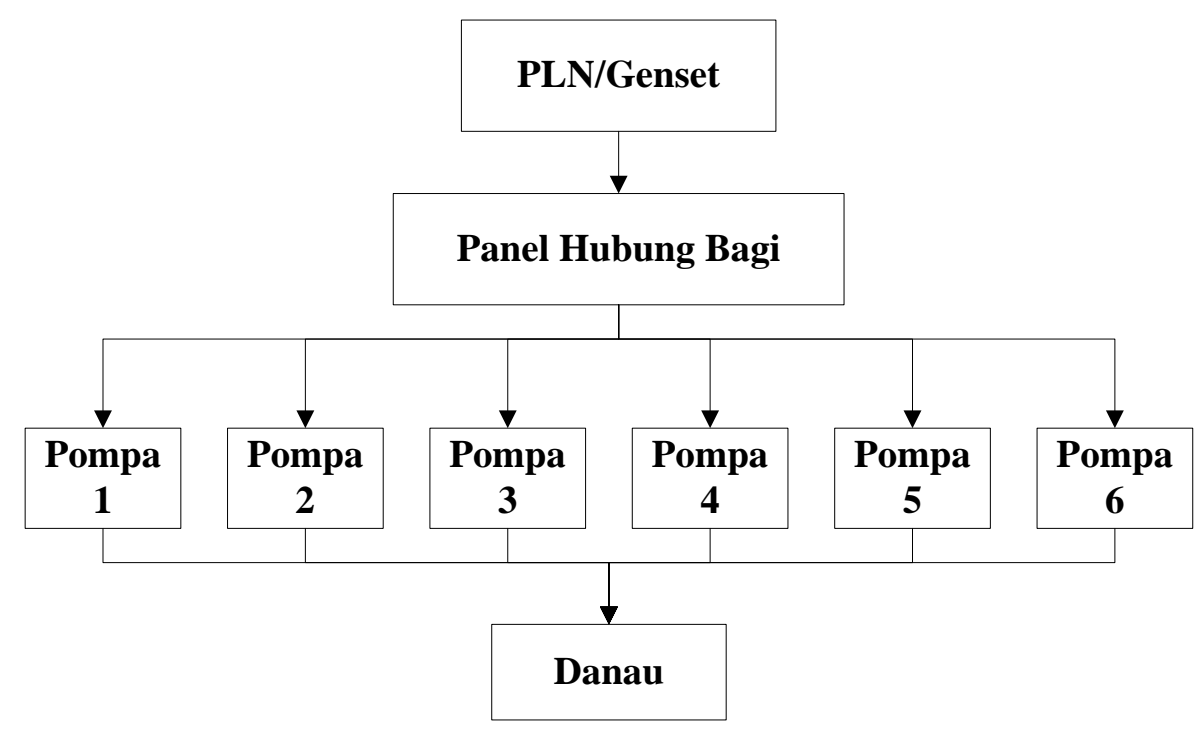

Gambar 1. Blok Diagram Pengoperasian Pompa secara Manual

Sistem pompa pembuangan air yang ada saat ini hanya dapat dioperasikan secara manual seperti yang digambarkan pada Gambar 1. Pengoperasian pompa dilakukan dengan mengoperasikan switch sebagai pengendalinya. Teknisi juga harus memperhitungkan secara manual berapa jumlah pompa yang harus dioperasikan. Perkiraan jumlah pompa yang dioperasikan diperoleh dengan melihat kondisi ketinggian air di danau terlebih dahulu.Jadi, teknisi harus melihat ke lokasi danau terlebih dahulu baru kemudian pergi ke pump house agar dapat menyalakan switch. Jarak antara pump house dan ruang teknisi berkisar $\pm 2 \mathrm{~km}$. Sistem pengoperasian dan adanya jarak ini dapat mengurangi kecepatan teknisi dalam mengoperasikan pompa apabila terjadi kondisi darurat.

\section{III.Perancangan Sistem}

Dengan memanfaatkan teknologi rangkaian mikrokontroler Arduino Uno dan beberapa kompponen elektronika, alat ini diharapkan dapat menggantikan sistem pengoperasian pompa pembuangan air danau pada sisi runwayyang masih dioperasikan secara manual. Konsep yang 
diinginkan adalah alat dapat menghidupkan maupun mematikan pompa secara otomatis berdasarkan kondisi ketinggian air di danau dan sungai sehingga teknisi tidak perlu datang ke lokasi untuk mengetahui keadaan level air atau pergi ke pump house untuk mengoperasikan pompa. Alat ini juga dirancang untuk dapat mematikan pompa apabila pompa kelebihan beban dan tidak dapat menghisap air. Dengan demikian, keberadaan alat ini diharapkan dapat mengurangi beban kerja teknisidan menunjang terciptanya keamanan penerbangan di lingkungan bandar udara.

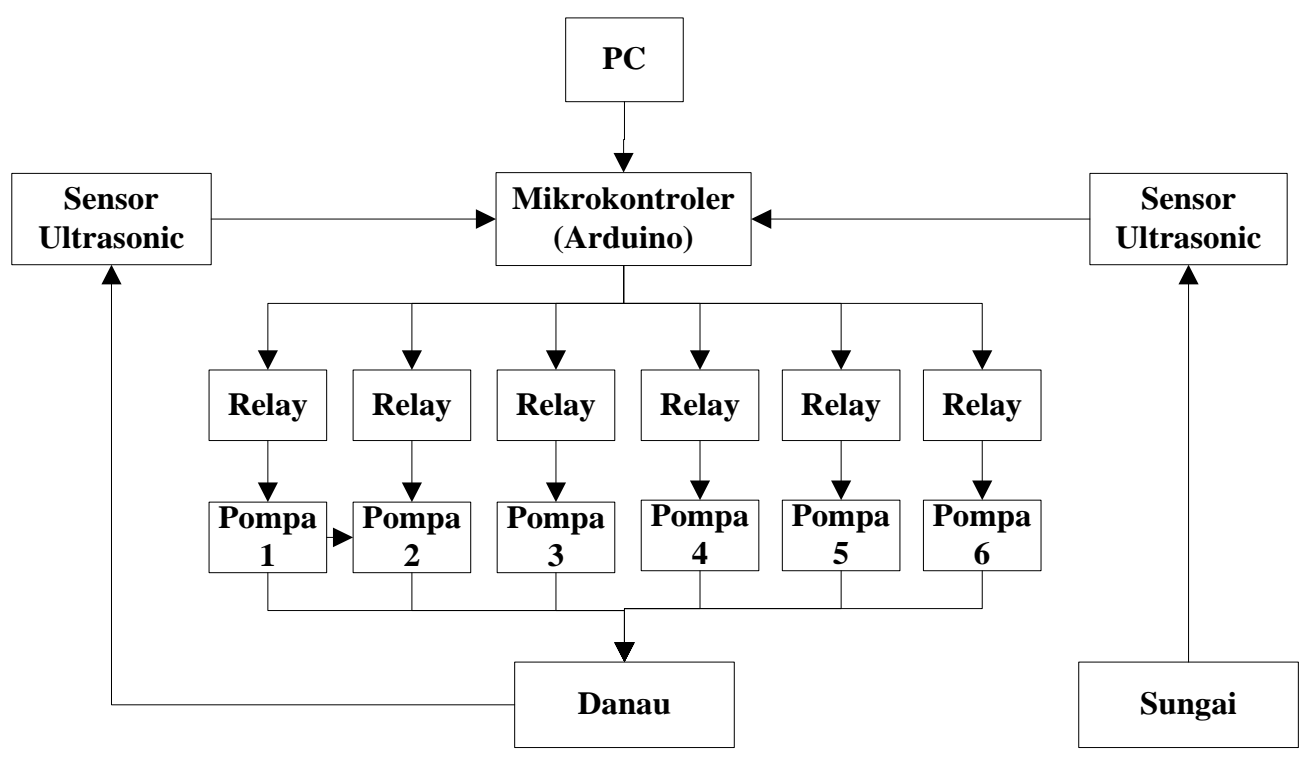

Gambar 2.Blok Diagram RancanganPengoperasianPompasecaraOtomatis

Pengoperasian sistem pompa pembuangan air danau ini dilakukan dengan mengirimkan data dari sensor ultrasonik ke Arduino Uno sebagai slave maupun sebaliknya. Jenis sensor ultrasonik yang digunakan adalah HC-SR04. Sensor ini mampu bekerja pada jarak jangkau dari $2 \mathrm{~cm}$ hingga $400 \mathrm{~cm}(1$ inci sampai $4 \mathrm{~m}$ ). Sistem menggunakan 2 rangkaiansensor ultrasonikyang dipasang pada sisi danau dan sungai. Hal ini bertujuan untuk memantau level ketinggian air danau dan sungai. Sensor ultrasonikpada sungai digunakan untuk indikator pompa diperbolehkan menyala atau tidak, sedangkan sensor ultrasonikpada danau digunakan sebagai indikator berapa banyak pompa yang akan menyala.Data dari sensor ultrasonik akan diteruskan kemikrokontroler di Arduino Uno yang selanjutnya akan menghasilkan perintah untuk menghidupkan maupun mematikan pompa.

Proses menghidupkan maupun mematikan pompa dilakukan oleh serangkaian aktuator yang bekerja berdasarkan perintah dari mikrokontroler. Rangkaian aktuator ini memiliki komponen utama berupa relai. Relai akan bekerja sesuai perintah dari mikrokontroler untuk mengidupkan dan mematikan pompa yang diinginkan sesuai kebutuhan.

Pengoperasian pompa akan dipantau oleh mikrokontroler pada Arduino Unodengan menggunakan sensor arus sensor arus ACS-712 yang dipasang pada pompa. Sensor arus akan memberikan informasi aktivitas pompa sehingga dapat diketahui pompa mana yang menyala maupun tidak beroperasi. Dari sensor ini pula dapat diketahui apabila terjadi beban arus lebih ketika pompa tidak dapat menghisap air. 


\section{Otomatisasi Pengoperasian Pompa}

Bandar udara Juanda memiliki 2 buah danau yang direpresentasikan sebagai $D\left(d \in D, D=\left\{d_{1}\right.\right.$, $\left.d_{2}\right\}$ ). Karena simulasi dilakukan dengan mengambil objek hanya 1 danau tanpa memandang identitas danau, maka danau hanya dinotasikan sebagai $d$.

Pompa air yangdisimbolkan sebagai $P$ berjumlah 6 buah untuk setiap danau $\left(p \in P, P=\left\{p_{1}, p_{2}\right.\right.$, $\left.\left.p_{3}, p_{4}, p_{5}, p_{6}\right\}\right)$. Pompa air akan dioperasikan secara terpisah sesuai kondisi yang diinginkan dengan memodelkan $P=0$ untuk kondisi pompa air mati dan $P=1$ untuk kondisi pompa air menyala.

Pengaturan pengoperasian pompa air didasarkan atas perbandingan ketinggian air danau yang direpresentasikan sebagai $h_{d}$ dan ketinggian air sungai yang direpresentasikan sebagai $h_{s}$. Ketinggian air danau $h_{d}$ dan ketinggian air sungai $h_{s}$ menjadi faktor pertimbangan utama dalam pengoperasian pompa air yang dapat diatur sedemikian rupa dalam berbagai referensi nilai. Nilai-nilai ini menunjukkan nilai ketinggian air sungai dan air danau yang sebenarnya dalam satuan meter $(\mathrm{m})$.

Penyalaan pompa baru diijinkan jika ketinggian air sungai tidak lebih dari $2 \mathrm{~m}\left(h_{s}<2 \Rightarrow P=1\right)$. Namun, jika ketinggian air sungailebih dari $2 \mathrm{~m}$, maka otomatis pompa tidak diijinkan untuk menyala $\left(h_{s} \geq 2 \Rightarrow P=0\right)$ meskipun ketinggian air danau lebih dari $3 \mathrm{~m}\left(h_{d}>3\right)$. Hal ini dipertimbangkan sebagai batas aman karena apabila ketinggian air sungai mencapai $2 \mathrm{~m}$ dan pompa dinyalakan, maka dikhawatirkan sungai akan meluap dan menggenangi rumah warga di sekitar bandar udara.

Berdasarkan kondisi ketinggian air danau, pompa air diijinkan menyala ketika ketinggian danau melebihi $3 \mathrm{~m}$ (pada kondisi ketinggian air sungai tidak lebih dari $2 \mathrm{~m}\left(h_{s} \leq 2, P \neq 0\right)$. Pemilihan pompa yang akan dinyalakan menggunakan sistem priority list, yaitu sistem daftar prioritas pompa yang sudah ditentukan urutannya.

Ketika level danau mencapai 3m dan tidak melebihi 3,2m $\left(3<h_{d} \leq 3,2\right)$, maka pompa 1 akan otomatis menyala $\left(p_{1}=1\right)$. Ketika level ketinggian air danau tidak melebihi $3,4 \mathrm{~m}\left(3,2<h_{d} \leq 3,4\right)$ maka pompa 1 dan 2 secara otomatis akan menyala $\left(p_{1,2}=1\right)$. Ketika level ketinggian air danau mencapai 3,6m $\left(3,4<h_{d} \leq 3,6\right)$, maka pompa 1,2 , dan 3 secara otomatis akan menyala $\left(p_{1,2,3}=1\right)$. Ketika level ketinggian air danau tidak melebihi 3,8m (3,6 $\left.<h_{d} \leq 3,8\right)$, maka otomatis pompa 1,2,3, dan 4 akan menyala $\left(p_{1,2,3,4}=1\right)$. Ketika level ketinggian air danau mencapai $4 \mathrm{~m}\left(3,8<h_{d} \leq 4\right)$, maka otomatis pompa $1,2,3,4$, dan 5 akan menyala $\left(p_{1,2,3,4,5}=1\right)$. Keenam buah pompa $\left(p_{1,2,3,4,5,6}=1\right)$ secara otomatis akan menyala semua ketika ketinggian air danau lebih dari $4 \mathrm{~m}\left(h_{d}>3,4\right)$.

Kondisi ini digambarkan sebagai

$$
P=\left\{\begin{array}{rl}
0, & h_{s} \geq 2 \text { atau } h_{d} \leq 3 \\
p_{1}=1, & 3<h_{d} \leq 3,2 \\
p_{1,2}=1, & 3,2<h_{d} \leq 3,4 \\
p_{1,2,3}=1, & 3,4<h_{d} \leq 3,6 \\
p_{1,2,3,4}=1, & 3,6<h_{d} \leq 3,8 \\
p_{1,2,3,4,5}=1, & 3,8<h_{d} \leq 4 \\
p_{1,2,3,4,5,6}=1, & h_{d}>4
\end{array} \quad, \forall p \in P\right.
$$




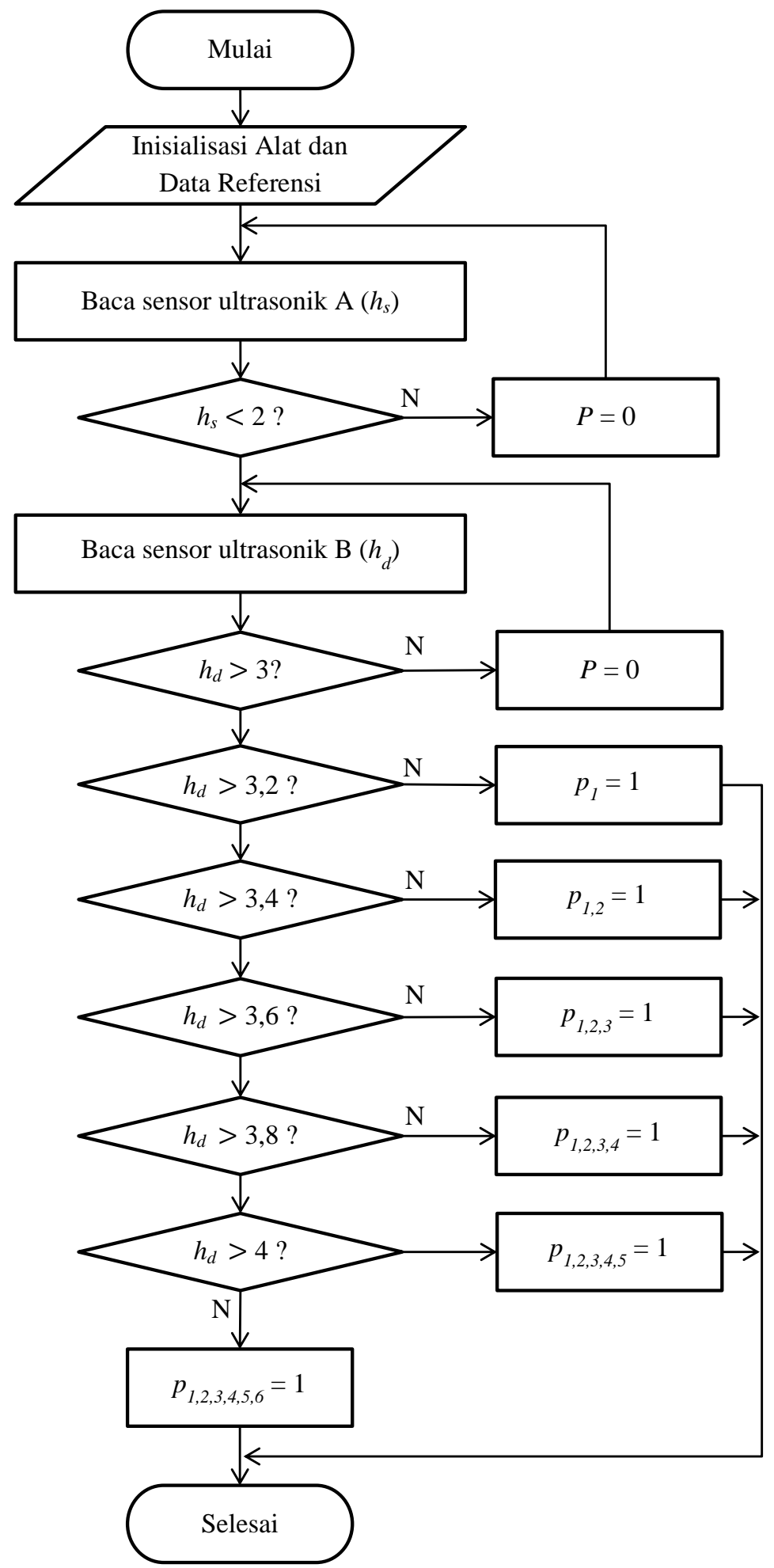

\section{Pengujian}

Gambar 3.Diagram AlirPengoperasian Pompa

Pengujian rancangan ini dilakukan dengan 8 percobaan sesuai dengan level ketinggian air danau $\left(h_{d}\right)$ dan level ketinggian air sungai $\left(h_{s}\right)$ yang sudah ditentukan referensinya. Percobaan dilakukan 
secara simulatif dengan menentukan nilai referensi dalam perbandingan skala lebih kecil, yaitu mengganti batas aman ketinggian air sungai dari $2 \mathrm{~m}$ menjadi $15 \mathrm{~cm}$ dan batas penyalaan pompa berdasarkan ketinggian air danau dari $3 \mathrm{~m}$ menjadi $8 \mathrm{~cm}$. Adapun interval atau rentang ketinggian air danau untuk penambahan pompa yang menyala ditentukan sebesar $8 \mathrm{~cm}$ (menggantikan 0,2 $\mathrm{m}$ ).

\section{Pengujian $\operatorname{Pertama}\left(h_{s} \geq 15 \mathrm{~cm}\right)$}

Pengujian pertama dilakukan dengan syarat $h_{s} \geq 15 \mathrm{~cm}$. Kondisi ini menggambarkan ketinggian air sungai lebih dari $15 \mathrm{~cm}$. Percobaan ini memperoleh hasil sebagai berikut.

Tabel 1. Hasil Pengujian Pertama

\begin{tabular}{|c|c|c|c|c|c|c|c|}
\hline $\begin{array}{c}\text { Level Sungai } \\
(\mathrm{cm})\end{array}$ & $\begin{array}{c}\text { Level Danau } \\
(\mathrm{cm})\end{array}$ & Pompa 1 & Pompa 2 & Pompa 3 & Pompa 4 & Pompa 5 & Pompa 6 \\
\hline 16 & 26 & OFF & OFF & OFF & OFF & OFF & OFF \\
\hline 17 & 28 & OFF & OFF & OFF & OFF & OFF & OFF \\
\hline 18 & 30 & OFF & OFF & OFF & OFF & OFF & OFF \\
\hline
\end{tabular}

Hasil pengujian menunjukkan bahwa ketika ketinggian air sungai lebih dari $15 \mathrm{~cm}\left(h_{s} \geq 15 \mathrm{~cm}\right)$, semua pompa tidak menyala. Hasil ini sesuai dengan hasil yang diharapkan.

\section{Pengujian Kedua $\left(h_{d}<8 \mathrm{~cm}, h_{s}<15 \mathrm{~cm}\right)$}

Pengujian keduadilakukan dengan syarat $h_{d}<8 \mathrm{~cm}$ dan $h_{s}<15 \mathrm{~cm}$. Kondisi ini menggambarkan ketinggian air sungai lebih dari $15 \mathrm{~cm}$ dan ketinggian air danau kurang dari $8 \mathrm{~cm}$. Percobaan ini memperoleh hasil sebagai berikut.

Tabel 2. Hasil Pengujian Kedua

\begin{tabular}{|c|c|c|c|c|c|c|c|}
\hline $\begin{array}{c}\text { Level Sungai } \\
(\mathrm{cm})\end{array}$ & $\begin{array}{c}\text { Level Danau } \\
(\mathrm{cm})\end{array}$ & Pompa 1 & Pompa 2 & Pompa 3 & Pompa 4 & Pompa 5 & Pompa 6 \\
\hline 8 & 4 & OFF & OFF & OFF & OFF & OFF & OFF \\
\hline 8 & 6 & OFF & OFF & OFF & OFF & OFF & OFF \\
\hline 8 & 7 & OFF & OFF & OFF & OFF & OFF & OFF \\
\hline
\end{tabular}

Hasil pengujian menunjukkan bahwa ketika ketinggian air sungai lebih dari $15 \mathrm{~cm}$ dan ketinggian air danau kurang dari $8 \mathrm{~cm}$ memperoleh hasil sama seperti pengujian pertama, yaitu semua pompa tidak menyala. Hasil ini sesuai dengan hasil yang diharapkan.

\section{Pengujian Ketiga( $8 \mathrm{~cm}<h_{d} \leq 16 \mathrm{~cm}, h_{s}<15 \mathrm{~cm}$ )}

Pengujian ketigadilakukan dengan syarat8 $\mathrm{cm}<h_{d} \leq 16 \mathrm{~cm}$ dan $h_{s}<15 \mathrm{~cm}$, yaitu ketinggian air danau lebih dari $8 \mathrm{~cm}$ dan kurang dari $16 \mathrm{~cm}$, serta ketinggian air sungai kurang dari 15 cm.Percobaan ini memperoleh hasil sebagai berikut.

\section{Tabel 3. Hasil Pengujian Ketiga}

\begin{tabular}{|c|c|c|c|c|c|c|c|}
\hline $\begin{array}{c}\text { Level Sungai } \\
(\mathrm{cm})\end{array}$ & $\begin{array}{c}\text { Level Danau } \\
(\mathrm{cm})\end{array}$ & Pompa 1 & Pompa 2 & Pompa 3 & Pompa 4 & Pompa 5 & Pompa 6 \\
\hline 8 & 10 & ON & OFF & OFF & OFF & OFF & OFF \\
\hline 8 & 12 & ON & OFF & OFF & OFF & OFF & OFF \\
\hline
\end{tabular}




\begin{tabular}{|l|l|l|l|l|l|l|l|}
\hline 8 & 14 & ON & OFF & OFF & OFF & OFF & OFF \\
\hline
\end{tabular}

Berdasarkan data hasil pengujian pada Tabel 3, hasil pengujian yang diperoleh pada nilai ketinggian air danau lebih dari $8 \mathrm{~cm}$ dan kurang dari $16 \mathrm{~cm}$ serta ketinggian air sungai kurang dari 15 $\mathrm{cm}$ memenuhi hasil yang diharapkan, yaitu hanya pompa 1 saja yang menyala, sedangkan pompa yang lain dalam kondisi mati.

4. Pengujian Keempat $\left(16 \mathrm{~cm}<h_{d} \leq 24 \mathrm{~cm}, h_{s}<15 \mathrm{~cm}\right)$

Pengujian keempatdilakukan dengan syarat $16 \mathrm{~cm}<h_{d} \leq 24 \mathrm{~cm}$ dan $h_{s}<15 \mathrm{~cm}$, yaitu ketinggian air danau lebih dari $16 \mathrm{~cm}$ dan kurang dari $24 \mathrm{~cm}$, serta ketinggian air sungai kurang dari 15 $\mathrm{cm}$. Hasil dari pengujian ini adalah:

Tabel 4. Hasil Pengujian Keempat

\begin{tabular}{|c|c|c|c|c|c|c|c|}
\hline $\begin{array}{c}\text { Level Sungai } \\
(\mathrm{cm})\end{array}$ & $\begin{array}{c}\text { Level Danau } \\
(\mathrm{cm})\end{array}$ & Pompa 1 & Pompa 2 & Pompa 3 & Pompa 4 & Pompa 5 & Pompa 6 \\
\hline 8 & 18 & ON & ON & OFF & OFF & OFF & OFF \\
\hline 8 & 20 & ON & ON & OFF & OFF & OFF & OFF \\
\hline 8 & 22 & ON & ON & OFF & OFF & OFF & OFF \\
\hline
\end{tabular}

Berdasarkan data hasil pengujian pada Tabel 4, hasil pengujian yang diperoleh pada nilai ketinggian air danau lebih dari $16 \mathrm{~cm}$ dan kurang dari $24 \mathrm{~cm}$ serta ketinggian air sungai kurang dari 15 $\mathrm{cm}$ memenuhi hasil yang diharapkan, yaitu hanya pompa 1 dan 2 saja yang menyala, sedangkan pompa yang lain dalam kondisi mati.

5. Pengujian Kelima $\left(24 \mathrm{~cm}<h_{d} \leq 32 \mathrm{~cm}, h_{s}<15 \mathrm{~cm}\right)$

Pengujian kelimadilakukan dengan syarat $24 \mathrm{~cm}<h_{d} \leq 32 \mathrm{~cm}$ dan $h_{s}<15 \mathrm{~cm}$, yaitu ketinggian air danau lebih dari $24 \mathrm{~cm}$ dan kurang dari $32 \mathrm{~cm}$, serta ketinggian air sungai kurang dari 15 $\mathrm{cm}$. Pengujian ini memperoleh hasil sebagai berikut.

Tabel 5. Hasil Pengujian Kelima

\begin{tabular}{|c|c|c|c|c|c|c|c|}
\hline $\begin{array}{c}\text { Level Sungai } \\
(\mathrm{cm})\end{array}$ & $\begin{array}{c}\text { Level Danau } \\
(\mathrm{cm})\end{array}$ & Pompa 1 & Pompa 2 & Pompa 3 & Pompa 4 & Pompa 5 & Pompa 6 \\
\hline 8 & 26 & ON & ON & ON & OFF & OFF & OFF \\
\hline 8 & 28 & ON & ON & ON & OFF & OFF & OFF \\
\hline 8 & 30 & ON & ON & ON & OFF & OFF & OFF \\
\hline
\end{tabular}

Berdasarkan data hasil pengujian pada Tabel 5, hasil pengujian yang diperoleh pada nilai ketinggian air danau lebih dari $24 \mathrm{~cm}$ dan kurang dari $32 \mathrm{~cm}$ serta ketinggian air sungai kurang dari 15 cm memenuhi hasil yang diharapkan, yaitu hanya pompa 1, 2, dan 3 saja yang menyala, sedangkan pompa yang lain dalam kondisi mati.

6. Pengujian Keenam $\left(32 \mathrm{~cm}<h_{d} \leq 40 \mathrm{~cm}, h_{s}<15 \mathrm{~cm}\right)$

Pengujian keenamdilakukan dengan syarat $32 \mathrm{~cm}<h_{d} \leq 40 \mathrm{~cm}$ dan $h_{s}<15 \mathrm{~cm}$, yaitu ketinggian air danau lebih dari $32 \mathrm{~cm}$ dan kurang dari $40 \mathrm{~cm}$, serta ketinggian air sungai kurang dari 15 $\mathrm{cm}$. Pengujian ini memperoleh hasil sebagai berikut. 
Tabel 6. Hasil Pengujian Keenam

\begin{tabular}{|c|c|c|c|c|c|c|c|}
\hline $\begin{array}{c}\text { Level Sungai } \\
(\mathrm{cm})\end{array}$ & $\begin{array}{c}\text { Level Danau } \\
(\mathrm{cm})\end{array}$ & Pompa 1 & Pompa 2 & Pompa 3 & Pompa 4 & Pompa 5 & Pompa 6 \\
\hline 8 & 34 & ON & ON & ON & ON & OFF & OFF \\
\hline 8 & 36 & ON & ON & ON & ON & OFF & OFF \\
\hline 8 & 40 & ON & ON & ON & ON & OFF & OFF \\
\hline
\end{tabular}

Berdasarkan data hasil pengujian pada Tabel 6, hasil pengujian yang diperoleh pada nilai ketinggian air danau lebih dari $32 \mathrm{~cm}$ dan kurang dari $40 \mathrm{~cm}$ serta ketinggian air sungai kurang dari 15 $\mathrm{cm}$ memenuhi hasil yang diharapkan, yaitu hanya pompa 1 hingga 4 menyala, sedangkan pompa 5 dan 6 dalam kondisi mati.

7. Pengujian Ketujuh $\left(40 \mathrm{~cm}<h_{d} \leq 48 \mathrm{~cm}, h_{s}<15 \mathrm{~cm}\right)$

Pengujian ketujuh dilakukandengan syarat $40 \mathrm{~cm}<h_{d} \leq 48 \mathrm{~cm}$ dan $h_{s}<15 \mathrm{~cm}$, yaitu ketinggian air danau lebih dari $40 \mathrm{~cm}$ dan kurang dari $48 \mathrm{~cm}$, serta ketinggian air sungai kurang dari 15 cm.Pengujian ini memperoleh hasil sebagai berikut.

Tabel 7. Hasil Pengujian Ketujuh

\begin{tabular}{|c|c|c|c|c|c|c|c|}
\hline $\begin{array}{c}\text { Level Sungai } \\
(\mathrm{cm})\end{array}$ & $\begin{array}{c}\text { Level Danau } \\
(\mathrm{cm})\end{array}$ & Pompa 1 & Pompa 2 & Pompa 3 & Pompa 4 & Pompa 5 & Pompa 6 \\
\hline 8 & 42 & ON & ON & ON & ON & ON & OFF \\
\hline 8 & 44 & ON & ON & ON & ON & ON & OFF \\
\hline 8 & 46 & ON & ON & ON & ON & ON & OFF \\
\hline
\end{tabular}

Data hasil percobaan pada Tabel 7 menunjukkan bahwa sistem pada kondisi ketinggian air danau lebih dari $40 \mathrm{~cm}$ dan kurang dari $48 \mathrm{~cm}$ serta ketinggian air sungai kurang dari $15 \mathrm{~cm}$ dapat memenuhi hasil yang diharapkan, yaitu hanya pompa 1 hingga 5 menyala, sedangkan pompa 6 dalam kondisi mati.

\section{Pengujian Kedelapan $\left(h_{d}>48 \mathrm{~cm}, h_{s}<15 \mathrm{~cm}\right)$}

Pengujian kedelapan dilakukandengan syarat $h_{d}>48 \mathrm{~cm}$ dan $h_{s}<15 \mathrm{~cm}$, yaitu ketinggian air danau lebih dari $48 \mathrm{~cm}$ dan ketinggian air sungai kurang dari $15 \mathrm{~cm}$. Pengujian ini memperoleh hasil sebagai berikut.

Tabel 7. Hasil Pengujian Kedelapan

\begin{tabular}{|c|c|c|c|c|c|c|c|}
\hline $\begin{array}{c}\text { Level Sungai } \\
(\mathrm{cm})\end{array}$ & $\begin{array}{c}\text { Level Danau } \\
(\mathrm{cm})\end{array}$ & Pompa 1 & Pompa 2 & Pompa 3 & Pompa 4 & Pompa 5 & Pompa 6 \\
\hline 8 & 49 & ON & ON & ON & ON & ON & ON \\
\hline 8 & 50 & ON & ON & ON & ON & ON & ON \\
\hline 8 & 51 & ON & ON & ON & ON & ON & ON \\
\hline
\end{tabular}

Data hasil percobaan pada Tabel 8 menunjukkan bahwa sistem pada kondisi ketinggian air danau lebih dari $48 \mathrm{~cm}$ dan ketinggian air sungai kurang dari $15 \mathrm{~cm}$ akan menyalakan semua pompa untuk bekerja bersama-sama. 


\section{Kesimpulan}

Berdasarkan hasil pengujian yang dilakukan, dapat ditarik beberapa kesimpulan:

1. Alat dapat bekerja sesuai dengan hasil yang diharapkan.

2. Rancangan sistem kontrol pengoperasian pompa secara otomatis ini dapat dipergunakan untuk mengganti sistem pengoperasian pompa yang masih dilakukan secara manual.

3. Penggunaan metode priority list dalam pengoperasian pompa harus diimbangi dengan pengecekan kondisi pompa secara berkala, terutama bagi pompa yang masuk dalam daftar prioritas utama.

\section{DAFTAR PUSTAKA}

[1] Akademi Teknik dan Keselamatan Penerbangan Surabaya. 2013.Modul Desain Sistem Kontrol. Surabaya : ATKP Surabaya.

[2] Kadir, Abdul. 2013. Panduan Praktis Mempelajari Aplikasi Mikrokontroler dan Pemrogramannya Menggunakan Arduino. Yogyakarta: Andi Offset.

[3] Kadir, Abdul. 2015. Buku Pintar Pemrograman Arduino. Yogyakarta: Mediakom.

[4] Kusumadewi, S. 2003.Artificial Intelligence : Teknik dan Aplikasinya. Graha Ilmu, Yogyakarta.

[5] Sianipar, Bonar. 2011. Visual Basic 10. Surabaya : ITS Press.

[6] Willa, Lukas. 2007. Teknik Digital, Mikroprosesor, dan Mikrokomputer. Bandung: Informatika. 